\title{
患者本人が決断した維持血液透析の見合わせについて，「維持血液透析の開始 と継続に関する意思決定プロセスについての提言」を運用するうえでの課題
}

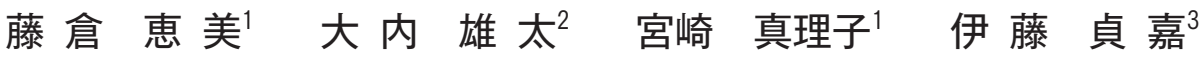 \\ ${ }^{1}$ 東北大学病院血液浄化療法部 2 岩切病院心療内科・精神科 \\ 3 東北大学大学院医学系研究科腎・高血圧・内分泌学分野
}

キーワード：血液透析継続の見合わせ，自己決定権，意思決定プロセス，緩和ケア

〈要旨〉

わが国では終末期医療に関するガイドラインが次々と発表され，いずれも患者本人の意思決定を尊重する内容に なっている．透析患者も同様に自らの意思を尊重され穏やかな最期を過ごすことが望ましい．われわれは狭義の終 末期とはいえない状況で患者本人が維持透析中止を決断した症例を想定し「維持血液透析の開始と継続に関する意 思決定プロセスについての提言」に沿って意思決定を行う過程と結果を検証した．その結果，患者がその病状や治 療に関して十分に検討，理解したうえで，ほかから強制されることなく意思決定しており，その判断に倫理的妥当 性があれば，治療中止は患者の自己決定権の行使として容認されるべきと考えた．ただし意思決定プロセスは慎重 に検証されなければならず, 加えて緩和医療に関する教育やコンサルテーション体制, 事後のグリーフケアを総合 的に整える必要がある．医療者が法的に免責される保証がないことにも十分注意すべきである.

\section{Agenda for adoption of the "Proposal for the Shared Decision-Making Process Regarding Initiation and Continuation of Maintenance Hemodi- alysis" (The Japanese Society for Dialysis Therapy, 2014)for patients who decide to withdraw from dialysis}

Emi Fujikura', Yuta Fujikura-Ouchi ${ }^{2}$, Mariko Miyazaki', Sadayoshi Ito $^{3}$

${ }^{1}$ Department of Blood Purification, Tohoku University Hospital, ${ }^{2}$ Department of Psychiatry, Iwakiri Hospital, ${ }^{3}$ Division of Nephrology, Endocrinology and Vascular Medicine, Tohoku University Graduate School of Medicine

Key words : withdrawal from dialysis, autonomy, Decision-Making process, palliative care

$\langle$ Abstract〉

Recently in Japan, several guidelines regarding terminal care issues have been published and all of them refer to respect for individual autonomy. Similarly, the preference of patients requiring maintenance hemodialysis (MHD) should be respected so that they may spend the rest of their lives peacefully. This study utilized a virtual scenario in which a patient decides to withdraw from MHD in a broadly- defined terminal state, and discusses the implications of both MHD cessation based on self-determination and medical care in and after the decisionmaking process, based on the "Proposal for the Shared Decision-Making Process Regarding Initiation and Continuation of Maintenance Hemodialysis" (The Japanese Society for Dialysis Therapy, 2014). The results of the study suggest that it is ethically permissible and proper to allow MHD cessation if patients properly discuss and adequately understand their medical conditions and treatments and are permitted to make decisions without external pressures when in a broadly- defined terminal state. However, the decision-making process must be reviewed carefully while considering contextual features. In Japan, health professionals also require continual awareness of the inconvenient fact that there is no law providing immunity. This study suggests agendas that will supplement the proposal. In conclusion, it is necessary to comprehensively develop education about palliative care, consultation systems and subsequent grief care.

藤倉 恵美 東北大学病院血液浄化療法部 $\quad$ T 980-8574 宮城県仙台市青葉区星陵町 1-1

Emi Fujikura Tel : 022-717-7392 Fax : 022-717-7486 E-mail : emifujikura@med.tohoku.ac.jp

〔受付日：2015年 6 月 11 日, 受理日：2015 年 10 月 19 日〕 
緒言

日本における終末期医療に関する議論は，がんの末 期患者や治る見込みのない植物状態の患者を想定して 始まった，その後，長期に療養生活を送り身体が衰弱 して亡くなる人が増えたことなどを背景として「末期 医療」が「終末期医療」という名称に変更され, 次々 とガイドライン ${ }^{1,2}$ が作成された. さらに最近「人生の 最終段階における医療」という名称が使用され3），患 者の意思を尊重し，人生の最終段階を穏やかに過ごせ る環境を整備することが目標とされている.

透析患者においても, 癌の末期状態や重度の脳機能 障害など治療の有無にかかわらずその死が近い状態で の透析治療の中止は, 尊厳死 (ここでは「尊厳ある死 $=$ death with dignity」人間としての尊篇を保って死に至 ること，つまり，単に「生きた物」としてではなく， 「人間として」遇されて，「人間として」死に至ること， ないしそのようにして達成された死を指す）や，延命 治療の中止の是非という観点から議論され, 2014 年日 本透析医学会から「維持血液透析の開始と継続に関す る意思決定プロセスについての提言」4) (以下「提言」) が発表された。この中で患者の尊厳を考慮したとき, 維持血液透析の見合わせも最善の治療となりうるとの 見解が示された。

一方で日本では延命治療に関する自己決定権の行使 に法的な裏付けはなく，尊厳死の定義や遂行の条件な どを定めた法律は未整備である．治療の非開始，見合 わせなどの重要な臨床上の決定についての法的な判断 は未決定であり，医療者は法的責任を問われる可能性 がある。

末期慢性腎不全患者は医学的処置を施さなければ早 期に死に至るという意味では「終末期患者」と捉えら れるが，透析治療を行えば社会復帰できる可能性があ ることから，死が差し迫っているような病状にある狭 義の終末期患者とは異なる，維持透析患者の診療に関 わる医療者は少なからず透析中止を考慮した経験を有 すると思われる．維持血液透析の中止を検討する状況 としては患者の全身状態が極めて重篤で回復が望めな い場合が多いと思われるが，狭義の終末期にあたらず 医学的に透析療法の施行は可能な状況で, 意思決定能 力がある患者本人が透析を止めたいとの希望を示す場 合もある.このようなケースでは現在の社会的状況か ら鑑みて治療方針の決定に際しょり慎重な対応が必要 になるが，先の提言にも具体的な方法は示されていな w.

\section{I ，検証の目的および方法}

維持血液透析の中止を決断した患者へ医療現場が適 切に対応できるよう，患者の自己決定を尊重するため の検討事項と課題を明らかにしたい.

維持血液透析患者が透析中止を決断した場合に検討 すべき問題を普遍化するために，実際の症例ではなく モデルケースを想定した。このモデルケースにおいて 提言に沿って意思決定プロセスを実施し，医学的観 点, 法的および倫理的観点から多元的に検討する.

\section{II . 症例（モデルケース）}

血液透析歴 15 年, 透析導入以降 $\mathrm{A}$ 病院の外来通院 透析を継続している 60 歳の女性患者. 夫と二人暮らし で子はおらず，夫以外の親族は患者の病状説明など診 療上関わったことがない。

病歴：長期透析の合併症により骨折を繰り返し全身 の痛みがあり日常生活動作 (activities of daily living : ADL）は徐々に低下していた。合併症の治療を勧めら れていたが, その度に「侵襲的な検査, 治療はしたく ない」という意思を示し拒否していた。

あるとき病的骨折を発症し歩行不能となった。精査 の結果, 症状の改善のためには手術が必要であるが, 重度の大動脈弁閉鎖不全症が発見され術前の検査が必 要と判明した. 患者は病状を理解したうえで心臓の精 査を拒否し, 疼痛緩和処置のみ希望した。退院時の ADL はほぼ寝たきりであったが, 自宅療養を強く希 望し介護サービスを利用して通院透析を継続すること になった。

退院 4 か月後, いつもどおり来院し透析を行い帰宅 した. 患者の帰宅後に夫が来院し「透析が辛いので透 析をやめて死を待ちたいと言っている」と相談があっ た. B 医師から透析を中止した場合の予後を説明し， 透析の時間や回数の減少など代替案を提案した。翌日 夫が再度来院し, 患者の透析中止の意思が変わらない こと, 夫もその意思を受け入れていること, 自宅での 苦痛緩和処置と看取りを希望していることを $\mathrm{B}$ 医師に 伝えた。 B医師のほかにこの患者を継続して診療して きた $\mathrm{A}$ 病院の複数の医師が協議した結果, 平常時と比 較し最近の患者の精神状態に変化がないことを確認し 判断能力があるものとして患者の希望に応じることと し，C往診クリニックに在宅での看取りの依頼を行っ た.

透析中止から 6 日目, 嘔気, 嘔吐出現. 翌 7 日目, 


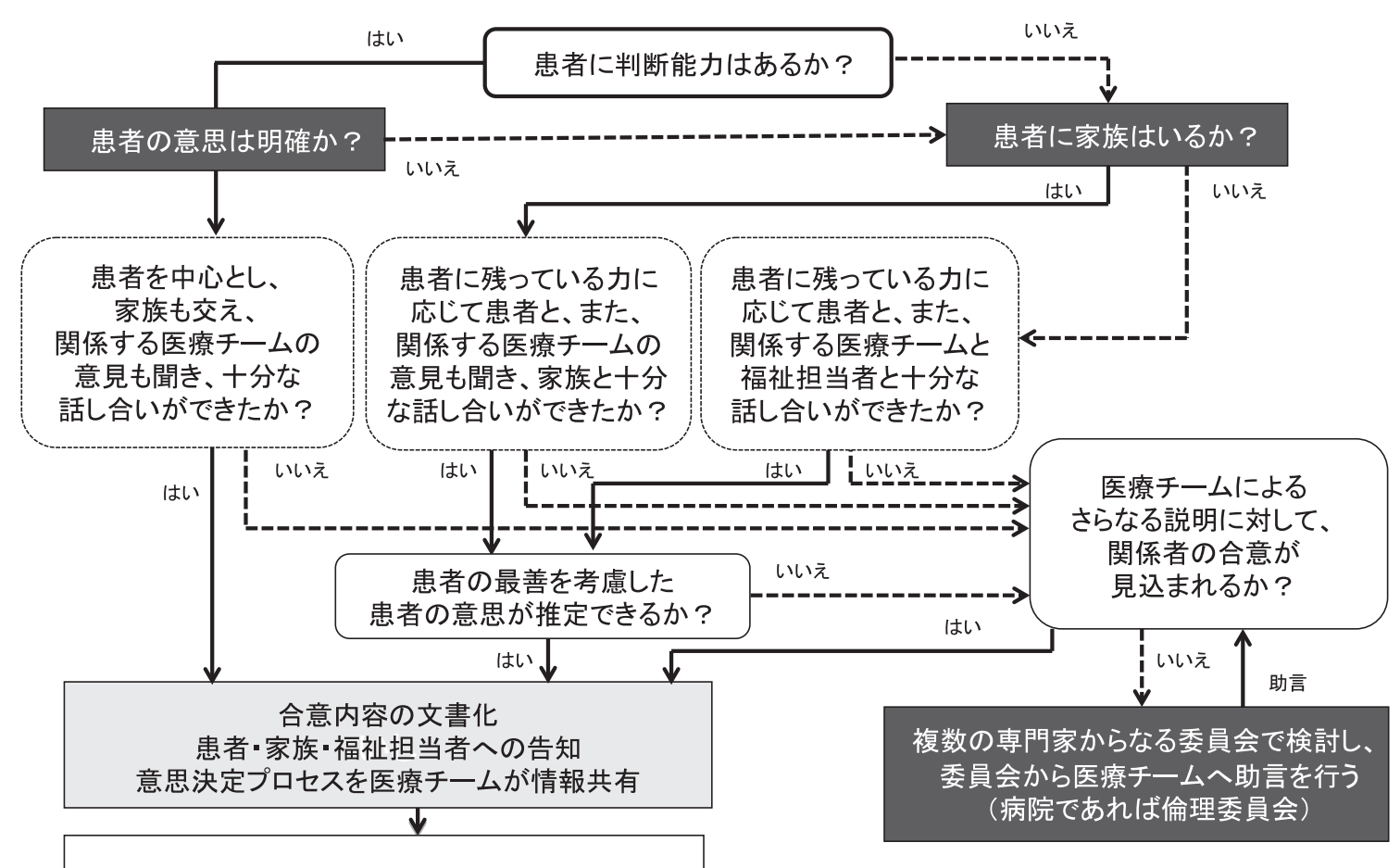

医療およびケアの方針決定

図 1 維持血液透析見合わせ時の意思決定プロセス

日本透析医学会(2014年)

(日本透析医学会. 透析会誌 $2014 ; 47: 269-85$ より引用)

未明に嘔気強く C 往診クリニックに診察依頼し, 塩酸 モルヒネ坐剤などが投与された。しかし苦痛が強いた め同日早朝に $\mathrm{A}$ 病院へ入院した. 入院後再度患者の意 思を確認した結果，透析中止の意思は変わらず入院継 続を希望し，苦痛緩和のみ行う方針となった。透析中 止から 9 日目に永眠した。 なお，透析中止に関する患 者，家族，医療者間の合意事項は文書化されている.

\section{III. 検討した事項}

1. 身体医学的観点から, 透析中止以前のインフォー ムドコンセントについて

提言 1 に「医療チームは患者に十分な情報を提供す る」と示されているが, 治療方針を決定するうえで, 病状に関する正確な情報を提供し患者の理解を得るこ とは病期にかかわらず必須である。透析患者が生命予 後に直結しない重篤な合併症を有することはまれでは ない. 合併症の治療選択, 予後など適切な時期に十分 な情報提供を行っていたかが重要である．モデルケー スでは，経過中に予測し得る症状や治療方針につき情 報提供されたが，侵襲的な検査，治療介入を受け入れ ないという自己決定が繰り返され，医療者はその意思 を尊重してきた経緯がある。

\section{2. 精神医学的観点から, 患者の意思決定能力および 精神疾患の有無の評価について}

提言に示される「維持血液透析見合わせ時の意思決 定プロセス」（図 1) において, 最初に患者に判断能力 があるか否かを判断することが示されている。モデル ケースでは, 平常時の言動や意思疎通性をもとに複数 の医師が患者の意思決定能力を評価した，治療中止決 定時に認知症やうつ病などの精神障害合併の有無や意 思決定能力の評価について精神科医の診断を受けるこ とが望ましいが, 受診同意や透析中止後の身体状況や 余命期間, 透析医療に精通した精神科医の不足などの 理由により難しい.

\section{3. 透析中止後の緩和ケアの観点から, 身体的な緩和 医療について}

終末期に患者が訴える苦痛や呼吸困難は薬物療法に よって軽減でき，とくにオピオイドが有用であること は議論の余地がない. 透析患者への緩和医療について はいくつかの文献 ${ }^{5 \sim 7)}$ で考察がなされており, 塩酸モ ルヒネは代謝産物の蓄積性のためにdo not useに分類 されている7). フェンタニルやオキシコドンは腎機能 の影響を受けにくく，近年貼付剤などさまざまな剂形 で上市されており,このようなケースでの苦痛緩和に も有用である。 
1. 患者の自己決定に影響を与え得る下記因子を検証し, 確認する.

1-1）森状態や認知症などの精神障害が患者の判断や意思決定能力に影響を与えていないか?

1-2）患者が，自己の尊厳よりも家族，集団主義，他者への配慮を過度に意識した価值観をもっていないか？

1-3）患者の経済状沉，家庭の事情等の社会経済的因子に関して状況を改善するために十分な対応がなされているか？（）

1-4）家族の意向による圧力がないか?

2. 透析中止以外の医療的選択肢の有無を検討し患者に呈示し，十分に理解できていることを確認する.

3. 患者が透析中止によりもたらされる結果（数日〜数週間以内の死）を理解していることを確認する.

4. 透析中止を動機づけている状態や症状など改善の余地がないことを再確認する．特に苦痛の軽減策は最新の知見に基づいて改善 の余地がないことを検討する.（*)

5. 患者の判断に迷いがないか確認する．時間をおいて複数回確認し，撤回や変更の自由があることを理解しているかを確認する.

6. 透析中止後行う治療や治療を受ける場所について確認する.（*)

7. 家族の意向，願い，家族から見た患者の意向（本心）について聴取し，家族の意向を確認する.

日本緩和医療学会による「緩和ケアチームの治療を 受けるがん患者のための鎮静に関するガイドライ ン $\rfloor^{8)}$ では鎮静も苦痛緩和に有用であることが示され ている．ただし「非がん患者への緩和ケア」という概 念が確立されているとはいえず，本人の同意があって も, 医学的適応, 倫理的妥当性について十分検討して から開始されるべきである.

\section{4. 法的観点から}

患者の自己決定権は憲法第 13 条（全て国民は，個人 として尊重される，生命，自由及び幸福追求に対する 国民の権利については，公共の福祉に反しない限り， 立法その他の国政の上で, 最大の尊重を必要とする) によって保証される。医療法では，医師，歯科医師， 薬剂師, 看護師その他の医療の担い手は,「適切な説明 を行い，医療を受ける者の理解を得るよう努めなけれ ばならない」とされ（第一条の四-2）患者の自己決定 を支援する義務を持つ．しかしながら患者の自己決定 による治療中止を具体的に担保する法律や判例は存在 せず，法的にはどの命も等しく最善を尽くされるべき であると考えられている，従って治療の非施行または 中止は刑法 199 条 (殺人罪), 刑法 202 条 (自殺関与. 同意殺人罪), 刑法 218 条 (保護責任者遺棄罪) に抵触 する恐れを含む。

正常な意思決定能力を有する患者が透析継続中止の 意思をもった場合，医療者がその自己決定に反して鎮 静や抑制を行ったうえで治療を強制することは人権侵 害とされるが，生命を維持する治療を中止することに よる訴追の可能性は拭いきれない.

過去に延命治療中止が行われた事例に対して違法と された判例では, 患者の余命の判断プロセス, 患者, 家族への情報提供抢よび意思決定プロセスが不適切で あると指摘された，現在の法制度のもとではモデル ケースに扔いて医療者が法的責任を問われる可能性は
否定できず，意思決定プロセスを文書により可視化し 保存することは最低限必須である。

\section{5. 倫理的観点から}

透析患者が正常な意思決定能力のもとで透析中止を 決断した場合に，医療者はその過程を患者とともに検 証しなければならない，治療中止の結果が患者に死を もたらすことを十分に理解しているか否か, 患者の理 解力の正しさ, 判断の強固さ, 判断に影響を与える要 因の有無, 治療を強制することの不適切さについて複 数のプロフェッショナルが繰り返し確認し, さらにそ れが記録として文書化されていることが重要である. 以上の条件が満たされた場合に, 患者が明確に拒否し ている治療的介入を行うことは，たとえその医療が一 般的に医学的有益性の高い介入行為であったとして も，患者の自己決定権の侵害になる，今回呈示したモ デルケースは血液透析の継続によって生命維持は可能 な状況であったが，重篤な合併症により堪え難い苦痛 を伴う状態が持続しており，治療を継続することが必 ずしも患者にとって有益ではない状況が他者からも明 らかであった。したがってこのようなケースで延命よ りも治療中止のほうが有益性において勝っているとの 判断には倫理的妥当性がある.

\section{6. 多元的検討によるモデルケースにおける透析見合 わせの判断の妥当性}

以上より, 維持血液透析患者が狭義の終末期といえ ない状況で透析中止の意思を示し医療者が透析見合わ せを決定する場合，透析医学会による提言に沿って意 思決定を行う必要があるが，透析見合わせの判断が妥 当だとするためにさらに表 1 に示す事項を確認すべき である。 


\section{IV . 考察〜わが国での腎不全診療において，提 言の意味とその活用のために}

\section{1. 腎不全診療における提言の位置づけ}

米国では法律上「自己決定権」が認められ，患者の 自己決定を尊重し従うことが規定されている，米国腎 臟医協会（Renal Physician Association：RPA）によ る透析開始及び透析中止に関するガイドライン は, 「锥告 5 透析の継続中止が容認される条件」とし て「判断力が正常である時点での自己決定」が極めて 重視されており，患者の重症度は考虑されていない． これは倫理的意思決定がなされるときに，患者の疾病 の種類（罹患臟器, 急性疾患か慢性疾患か, 悪性か非 悪性か), 病期, 予後, 障害の程度などの影響は受けな いという考え方 ${ }^{10)}$ に基づいている.

わが国には生命を維持する治療の非開始，治療中止 について法的な拘束力をもつ明確な「ハード・ロー」 はなく,「ソフト・ロー」といわれる専門家により作成 されたガイドラインが判断の妥当性の拠り所となって いる. 2007 年に厚生労働省が「終末期医療の意思決定 プロセスに関するガイドライン $]^{1)}$ を作成した。 この中 で患者本人の意思が基本となること，治療方針は医療 チームで判断することなどの基本方針が示された，そ して 2012 年に日本老年医学会より「高齢者の終末期の 医療およびケア」に関する「立場表明」11)が出された。 高齢者の終末期としての状態像をがんに限定せず，身 体が衰弱し，長期に療養生活を送った後に亡くなるこ とも想定された内容となっている.この中では,「本人 にとって最善の医療㧍よびケア」を受ける権利がある こと,「何らかの治療が, 患者本人の尊厳を損なったり 苦痛を増大させたりする可能性があるときには, 治療 の差し控えや治療からの撤退も選択肢として考慮する 必要がある」と示した。この立場表明は高齢者の治療 中止に関するソフト・ローのひとつとして医療現場へ 一石を投じた．続いて 2014 年 3 月に厚生労働省が発表 した「終末期医療に関する意識調査」12)では,「終末期 医療」という用語が「人生の最終段階における医療」 に変更された。「人生の最終段階における医療」のあり 方として，医療行為のみに注目するのではなく，最期 まで尊厳を尊重した人間の生き方に着目し，幅広く医 療及びヶアの提供について検討していくことに重点を おくと謳われている。調查内容も，がんの末期状態や 植物状態のような「狭義の終末期」を想定した内容か ら脱し, 高齢者や慢性疾患などの「非悪性疾患」患者 への医療の提供㧍よび治療の中止, 事前指示書にまで
検討の範囲を広げている.

一連の終末期医療に関するガイドラインの変遷は, 腎不全医療のあり方に対しても，患者の人生に打ける 医療の位置づけを考慮するよう求めているように読み 取れる。透析医療の黎明期には医療資源の限界のため に救命できなかった患者が存在した，現在の日本では 医療資源が充足し，医療保険制度や腎不全医療への公 的補助が整い，患者の権利を尊重した透析医療が提供 可能である。医療は進歩し高齢者や重大な合併症を有 する患者への透析導入や長期透析患者は特別ではなく なった，すると新たな問題として，癌の末期状態や重 度の脑機能障害など, 腎代替療法が患者の予後を改善 しないことが䯚念される場合に, 透析を開始, 継続す るか否か透析医療の現場では暮藤が続いていた。 そこ で透析医療領域での終末期医療の指針作成が切望さ れ，2012 年に「慢性血液透析療法の導入と終末期患者 に対する見合わせに関する提言(案) 」13)が公開された。

筆者らはこれに対しパブリックコメントを提出し た。 パブリックコメントの作成にあたっては RPA の

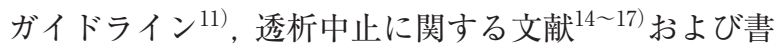
籍18,19)を参考にし, 治療中止の決定に際しては意思決 定のプロセスが重要と考え, 以下の意見を提出した.

提言の対象は終末期患者に限定せずすべての維持血 液透析患者を対象とするべきで，対象患者が「狭義の 終末期」状態であるか否かにかかわらず，患者本人の 意思決定能力を評価し共同の意思決定を行うことが重 要である. また，日本における透析中止について法的 解釈を行った文献はいくつか存在するが20,21), 参考と なる判例はなく現在のところグレーゾーンと解釈され ている.とくに本研究で用いたモデルケースのように 合併症が生存期間を強く規定しない場合には治療中止 の妥当性を担保するためのソフト・ローが必要と考 え, 意思決定プロセスを実施するうえでの確認事項と して表 1 に示した内容を提案した.

2014 年に日本透析医学会より発表された提言では 維持血液透析の開始と継続について, 患者の自己決定 を尊重すること，患者の尊厳を考慮したとき，維持血 液透析の見合わせが最善の治療となる場合もあること が示された．しかしながら診療現場では提言の「透析 の見合わせを検討する状況」のみが注目されており， 「条件を満たせば血液透析を中止してよいのか? 」とい う疑念はまだ残っているように思われる。

\section{2. 患者の自己決定の尊重のために注意すべき事項}

患者の自己決定は最優先されるが，医療者は盲目的 に承認するのではなく，患者の判断に影響を与える因 子（表 2）が存在しないか注意しなければならない. 


\section{表 2 患者の自己決定に影響を与え得る因子}

- 患者の意思判断能力の正常さ. 榣や認知症など意思判断能 力に影響を与え得る疾患の存在

・症状や予後，治療方法やほかの医療的選択肢に関する情報 不足, 理解不足

・経済状況，家庭の事情などの社会的圧力

・家族の意向による圧力

- 日本人的な価值観 (個人主義よりも家族/集団主義. 他者へ の配虑）

さきに検討したような社会的圧力や医学的な情報不足 のほかに，日本人および日本文化の特性として，個人 よりも家族・集団主義，曖昧，他律，協調性を重んじ る傾向など，自己の尊厳のための自己決定を阻害しう る要因がある。こういった特性により，医療倫理領域 の重要原則である「自律尊重, 自己決定と自由, 尊厳,

公平，多様性」が尊重されない状況が生み出される可 能性がある。岡田らによる透析医に対する意識調查 ${ }^{22}$ でも，終末期の透析中止を指示する事前指示書が存在 しても，家族の意向がその内容と異なる場合には医療 者は家族の意向を優先する傾向がみられた，患者の自 己決定を尊重するうえで家族の同意は必須ではない が，臨床現場では家族の意向が考虑されることが多い ことにも配慮が必要である.

そこで提言の運用にあたっては，提言に示された意 思決定プロセスを実施する際に各項目について十分に 吟味し検討すべきである。モデルケースのように，生 存期間を強く規定する合併症がなく狭義の終末期には あたらないが，治療継続による延命よりも治療中止の ほうが患者にとって有益性に勝る状況であることが, 患者，家族，医療者すべてが了承できる状況である場 合に, 表 1 に示した事項を確認することができれば, 透析の見合わせを患者の自己決定権の行使として受け 入れるべきとわれわれは考える．前述したような日本 文化の特性，司法判断の現状を鑑みて，患者の自己決 定をもとに家族の意向を確認し，医療チームで治療方 針を決めることが重要である，もち万ん患者，家族， 医療者の間で合意した事項について，その決定プロセ スも含め文書化しておくことは必須である.

\section{3. 透析見合わせ後の緩和ケア〜家族への精神的サ ポートも含めて}

透析の見合わせを決定した後には適切な緩和ケアが 必要である，提言 5 では「患者の全人的な苦痛に対応 する」ことを鹰めている．身体的な痛み一の対策は先 に述べた．精神的ケアについては堀川らの意見 ${ }^{23}$ が参 考になる，具体的には，(1) 身体的ケアをていねいに行 う, (2) 適切なサポート体制を整える, (3) 支持的精神療 法, (4) 向精神薬による薬物療法である.
それまで継続してきた生命維持のための治療を自ら の意思で中断するという決断は, 血液透析患者の場合 余命を 1 2 週間以内と患者自身が決定することであ り，それを家族や医療者も自覚しているという状況を 生み出す，治療中止の決定に至るまでに長い経過があ る一方でその後に残された時間は短く，患者自身が透 析を中止する判断はがん患者が積極的治療から緩和治 療に切り替える決断とは似て非なるものである. Chater $ら^{24)}$ は透析中止を決断した患者の緩和ケアを 行った報告をしているが，このような患者の心理は 「あきらめ」とも「満足」とも「受容」とも分類しきれ ないと述べている，提言 5 では患者の家族に対する精 神的, 社会的支援にも触れられている. 前述の Chater $ら^{24)}$ は，透析中止の決断について，患者よりも家族の ほうがその判断について「良いとも悪いともいえる」 と考える割合が多かったと報告している，患者の意思 を尊重しその死を容認した家族は，意思決定の過程で も，患者の死後も，迷いや自責の念をもつであろう. 長期にわたって患者の透析生活を支えてきた家族の衰 失感など心理面の変化に関してはほとんど知られてい ない，今後同様のケースについて検討を重ねる必要が ある。

\section{4. 透析見合わせに関わった医療者にかかるストレス}

透析患者に関わる看護師のストレスに関する調査で

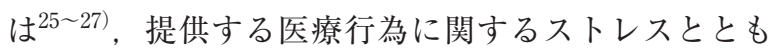
に患者との人間関係もストレスの原因になることが示 唆されている，外来透析部門のスタッフには，長期に わたって患者の日常生活の一部でありながら生命維持 に必須の治療を提供してきた中で築かれた患者一医療 者関係がある。この深い関係性の中で，透析中止を自 己決定した患者の存在は医師も含めたスタッフに自責 の念をもたせることは十分に考えられる。一方，一般 病棟で緩和ケアを提供するスタッフのストレスとして 中島ら ${ }^{28)}$ は「緩和ケアに対する知識不足，急性期と終 末期の患者の異なる看護の困難さを抱えながら看護し ている」と報告している。緩和ケアの知識や経験にそ しい一般病棟の看護スタッフには, 透析中止により死 に向かう患者の看護は難しく大きなストレスになるで あろう。モデルケースのような症例に関わる医療者の 心理的負担を軽減することも重要な課題である.

\section{5. 透析見合わせ後の緩和ケアにおける今後の課題}

現在緩和ケアの一環としての精神療法を行える透析 医療従事者は極めて少ない。わが国の診療報酬や緩和 ケア病床の整備状況などの事情から, 維持透析患者が 緩和ケア病棟で最期を迎えることは難しく, 終末期を 迎えた透析患者が専門的な精神科的ケアも含めた緩和 
ケアを受けられる状況はまれである。透析医療に関わ るスタッフが緩和ケアのトレーニングを受けること や，家族，医療スタッフも含めた精神科的なサポート およびコンサルテーション体制の充実も今後の検討課 題である.

\section{まとめ}

維持血液透析患者の透析の見合わせを検討する場合 に，日本透析医学会による提言に沿って意思決定を行 うことが必要であるが，提言の運用，治療方針決定は 慎重に行われなければならない．患者の自己決定を尊 重するうえで患者の病期, 重症度は影響がない. 患者 が透析治療中止を自己決定した場合には，意思決定プ ロセスを検証し，治療中止が患者の自己決定権に基づ いた治療方針として尊重され得るべきものであるか医 療チームで判断することが重要である。透析中止が決 定された場合には精神的ケアも含む適切な緩和ケアを 提供すべきである。これらによって，合併症の回復が 望めず死が差し迫っている患者だけでなく，余命の期 間が明らかに限定されていない患者であっても，透析 中止は医学的, 倫理的に妥当な選択となりうる。しか し法制度が未整備である現状では治療中止の判断に至 るプロセスは真正性を保ち見読できる文書として保存 することが重要である。このような判断を適切に行う ためには事例発生時に医療チームの判断を支援するコ ンサルテーション体制, 透析スタッフが緩和医療の考 え方や実践に関して学習する機会, 事後のグリーフケ アを総合的に整えていかねばならない.

謝辞：本論文の端緒となった日本透析医学会へのパブリッ クコメント提出にあたり指導を受けた故 関野宏先生 (2013 年 8 月逝去）に感謝いたします.

\section{文献}

1）厚生労働省：終末期医療の決定プロセスに関するガイ ドライン. http://www.mhlw.go.jp/shingi/2007/05/ dl/s0521-11a.pdf（access 2015.8.18）

2）日本医師会第 $X$ 次生命倫理懇談会：終末期医療に関す るガイドライン. http://dl.med.or.jp/dl-med/teireikaiken/20080227_1.pdf（access 2015.8.18）

3）終末期医療に関する意識調査等検討会：終末期医療に 関する意識調査等検討会報告書, 2014. http://www. mhlw.go.jp/file/05-Shingikai-10801000-IseikyokuSoumuka/0000041846_3.pdf（access 2015.8.19）

4) 日本透析医学会：維持血液透析の開始と継続に関する 意思決定プロセスについての提言. 透析会誌 2014 ;
47: 269-85.

5) Davison SN. Integrating palliative care for patients with advanced chronic kidney disease: recent advances, remaining challenges. J Palliat Care 2011; 27: 53-61.

6) Fassett RG, Robertson IK, Mace R, Youl L, Challenor S, Bull R. Palliative care in end-stage kidney disease. Nephrology 2011; 16: 4-12.

7) Mid-Atlantic Renal Coalition and Kidney End-of-Life Coalition: Clinical Algorithm \& Preferred Medications to Treat Pain in Dialysis Patients, Midlothian, Virginia：Mid-Atlantic Renal Coalition, 2009.

8）日本緩和医療学会 緩和医療ガイドライン作成委員 会. 苦痛緩和のための鎮静に関するガイドライン, 2010 年版. https://www.jspm.ne.jp/guidelines/seda tion/2010/index.php (access 2015.8.18)

9) Renal Physicians Association: Clinical Practice Guideline Second Edition. Shared Decision-Making in the Appropriate Initiation of and Withdrawal from Dialysis. Rockville, Maryland: Renal Physicians Association, 2010.

10）浅井篤. 緩和ケアに関連する倫理的問題. 大石醒悟, 高田弥寿子, 竹原歩, 平原佐斗司 編. 心不全患者の 緩和ケア. 東京: 南山堂, $2014 ; 213-23$.

11）日本老年医学会.「高齢者の終末期の医療およびケア」 に関する日本老年医学会の「立場表明」, 2012. http:// www.jpn-geriat-soc.or.jp/tachiba/jgs-tachiba2012. pdf (access 2015.8.18)

12）終末期医療に関する意識調査等検討会. 人生の最終段 階における医療に関する意識調査報告書, 2014. http://www.mhlw.go.jp/file/04-Houdouhappyou10802000-Iseikyoku-Shidouka/0000042775.pdf(access 2015.8.18)

13）岡田一義, 大平整爾, 伊丹儀友, 他. 慢性血液透析療 法の導入と終末期患者に対する見合わせに関する提言 (案). 透析会誌 2012；45：1090-5.

14）大平整爾. 透析非導入（見送り）と透析中止（差し控 え）への一考察. 透析会誌 2008；41：761-70.

15）岡田一義. 終末期における透析中止. 透析会誌 2008; 41: 29-37.

16) Cohen LM, Germain MJ, Poppel DM. Practical considerations in dialysis withdrawal: "To have that option is a blessing”. JAMA 2003; 289: 2113-9.

17) Hirsh DJ, West ML, Cohen AD, Jindal KK. Experience with not offering dialysis to patients with a poor prognosis. Am J Kidney Dis 1994; 23: 436-66.

18）大平整爾. 透析患者のターミナルケア一生と死のはざ まにある医療と看護. 大阪：メデイカ出版, 2011.

19）会田薰子. 延命医療と臨床現場一人工呼吸器と胃ろう の医療倫理学. 東京: 東京大学出版会, 2011.

20）小川義龍．透析非導入・中止に打ける患者の自己決定 権. 透析会誌 2012；45：1104-5.

21）竹中郁夫. 透析中止に関連する法的問題. 臨牀透析 
2009; 25: 1455-60.

22）岡田一義, 今田聰雄, 海津嘉蔵, 他. 透析医への意識 調査：維持血液透析患者の悪性腫瘍終末期における透 析中止について．透析会誌 2003；36：1315-26.

23）堀川直史, 倉持泉, 樋渡豊彦, 他. 終末期にある患者 およびその家族との接し方（2）精神科医の立場から： 腎不全患者を中心に. 臨牀透析 2009；25：1435-43.

24) Chater S, Davison SN, Germain MJ, Cohen LM. Withdrawal from dialysis: a palliative care perspective. Clin Nephrol 2006； 66: 364-72.

25）大平整爾．透析スタッフのストレス実態. 臨牀透析
2011；27: 1669-76.

26）米田千恵子, 丸山祐子, 原田孝司, 他. 透析室におけ る看護師のストレスの特徴. 臨牀透析 2009；25：3117.

27）石丸律子, 秋永和之, 梅崎節子, 他. 人工透析施設に 勤務する看護師のストレスに関する研究一オープンフ ロアという治療環境の影響について. バイオメデイカ ル・ファジィ・システム学会誌 2012；14：43-9.

28）中島里子, 角田直枝. 緩和ケアに携わる看護師のスト レスー一般病棟の場合一. 緩和医療学 $2000 ； 2 ： 96-$ 101. 